\title{
BAHRAIN'S ARRESTED REVOLUTION
}

\author{
Stephen Zunes
}

\begin{abstract}
This article provides an overview and analysis of the 2011 pro-democracy struggle in Bahrain, focusing in particular on the role of strategic nonviolent action and the foreign policy of the United States. It argues that Bahrain's progressive and pluralistic tradition would have made the possibilities of a democratic transition more promising than in many Arab states, but the ruthlessness and uncompromising posture of the government, combined with Saudi-led intervention and a refusal by the United States to support democratic forces, led to the movement's suppression. The article also challenges exaggerated accounts of the sectarian dimension of the conflict and faults the United States for its ongoing support for the Bahraini regime as a major contributor to the failure of the pro-democracy struggle.
\end{abstract}

Keywords: nonviolent action, pro-democracy movements, repression, US policy, Arab Spring, arms

Of the popular pro-democracy civil insurrections which swept the Middle East in 2011, none were as large - relative to the size of the country — as the one which took place in the island kingdom of Bahrain. And, while scattered resistance continues, none were so forcibly and thoroughly suppressed.

The crackdown against the overwhelmingly nonviolent pro-democracy struggle launched in mid-February was brutal. Over 40 people have been killed by security forces and pro-government mobs and more than 1,600 have been arrested. As the government's own Bassouini Commission acknowledged, many detainees have been tortured and there have been several deaths of those in custody. Those targeted by security forces were not just the pro-democracy protesters themselves, but journalists who covered the demonstrations and medical personnel who treated victims, including Dr. Ahmed Jamal, president of the Bahrain Medical Society. In October, a military court sentenced 20 doctors and nurses to up to 15 years in jail for assisting the wounded.

More than 4,400 people have been dismissed from their jobs for supporting the pro-democracy movement and over 40 mosques and religious sites deemed to have links to pro-democracy activists were destroyed. Human Rights Watch reports that "Leading political opposition figures, human rights defenders, and civil society activists have been sentenced to unduly long prison terms, in some cases for life,

Stephen Zunes is Professor of Politics and Chair of Middle Eastern Studies, University of San Francisco.

ASQ 35.2 Produced and distributed by Pluto Journals 
solely for their role in organizing the large street protests; their trial record does not link them in any way to acts of violence or any other recognizable criminal offense."

One of the tragedies of the ongoing struggle in Bahrain is that with one of the more liberal monarchies in the region and a largely moderate and middle class opposition, compromise should have been possible. The largely nonviolent protests by pro-democracy activists in the neighboring emirate of Kuwait in 2006, known as the "Orange Revolution," and a series of subsequent protests have led to a series of major reforms in that sheikdom. By contrast, events in Bahrain have led to moderates within both the regime and in the opposition being sidelined by hard-liners, making compromise more difficult. Failure of the democratic movement could be a bad precedent for democratic movements and could increase sectarian divisions elsewhere in the region.

Hard-liners within the government were strengthened by pressure from the Saudi regime to crack down. The Saudis fear that a successful Shia-led pro-democracy struggle in Bahrain might not only encourage pro-democracy elements in their kingdom, but might encourage the restive and oppressed Shia minority in Saudi Arabia — which is concentrated in the oil-rich northeastern part of the country-to rebel as well. Ironically, both King Hamad and particularly his son, the crown prince, are generally thought to be in the moderate camp. However, the king's influential uncle, Prime Minister Khalifa ibn Salman Al Khalifa — who has been in power far longer than the king - appears to have won out in his uncompromising position toward the opposition. The crown prince has been marginalized and the moderate Wefaq opposition - once willing to work with the government - has now taken its politics to the streets.

Meanwhile, repression against the opposition, despite their moderate reformist demands, has led increasing numbers of activists to no longer call simply for reforms within the monarchy, but for the abolition of the monarchy itself, which is considered nothing less than treasonous by authorities.

\section{A Popular Progressive Tradition}

The authoritarianism and repression by the current Bahraini government contrasts with the island's relatively progressive and pluralistic tradition.

Though Bahrain has a long and rich history, the modern state did not receive full independence from Great Britain until 1971. This is the same year the British withdrew their security commitments from the area and the United States stepped in as the major foreign power. Bahrain is the smallest country in the Middle East, located on an island of only 290 square miles (smaller in area than New York City) in the Persian Gulf between Qatar and Saudi Arabia. Its population is only 1.2 
million (smaller than San Antonio, Texas). More than half of that total consists of foreign guest workers, primarily from South Asian countries.

Despite many years under monarchies and empires, Bahrainis have long embraced a tradition of freedom and social justice. During most of the tenth and eleventh centuries, an Islamic sect known as the Qarmatians governed the island and created a radically egalitarian society based on reason and the equal distribution of all wealth and property among the adherents. In the nineteenth century, Bahrain was the largest trading center in the entire Gulf region-with Arab, Persian, Indian, and other influences - reinforcing traditions of cosmopolitanism, tolerance, and pluralism.

A visit to the capital Manama today reveals not only Sunni and Shia mosques, but Christian churches, Hindu and Sikh temples, and a Jewish synagogue. Bahrain was the first Arab country in the Gulf to provide formal modern education to women. With an economy traditionally based on fishing, pearl diving, and trade - and with too little land for much grazing or fresh water for farming-Bahrain has been a largely urban society for centuries, even prior to the discovery of oil. Thus, it has never been subjected to the kind of parochial tribalism of other countries on the Arabian peninsula. Furthermore, unlike the other oil-rich sheikdoms of the Gulf region, the diverse sources of its wealth have led to the establishment of an indigenous middle class.

Though an island, Bahrain is accessible by road. A 16-mile causeway connects it to Saudi Arabia. Indeed, Bahrain's relatively liberal social mores have made it a residence of choice for Saudis who wish to live in a less restrictive environment. It has also become a popular weekend destination for Saudis who want to party.

Although Bahrain's oil supplies are running out, it serves as a major refinery center. It still has plenty of natural gas reserves and has become a major financial center. Ship repair, aluminum refining, and light manufacturing have also helped diversify the economy. With an annual per capita income of $\$ 26,000$ (similar to Greece), low unemployment, a literacy rate over 90 percent, and an average life expectancy and infant mortality rate comparable to some European countries, it is one of the better-off nations in the Middle East.

Still, impressive social and economic statistics are no substitute for political freedom, particularly when combined with ongoing discrimination against the Shia majority. Even the US State Department has acknowledged that the Bahraini government "restricts civil liberties, freedoms of press, speech, assembly, association, and some religious practices."

The 1990s saw periodic and widespread protests throughout Bahrain, including scattered acts of violence, against the authoritarian Sheik Issa. When Issa died in 1999, his son and successor King Hamad announced a series of major reforms. Approval of the National Action Charter of Bahrain, codified in a 2001 referendum, ended more than seven years of protests against the regime. While Bahrainis did 
enjoy a somewhat more liberal social and political environment under their new ruler, most promised reforms never materialized. For example, the Charter allowed for the establishment of an elected lower house of parliament, but it has remained largely powerless and the electoral districts were gerrymandered to favor those supporting the policies of the government. The upper house-appointed by the king - must approve any legislation passed by the lower house. Furthermore, the king can still veto any legislation with no option of override and can abolish the entire parliament at will. All of the important cabinet posts - and a majority of the cabinet posts overall — are filled by members of the royal family. Most important is the prime minister, Prince Khalifa, reputedly the richest man in Bahrain, who has governed for nearly 40 years. The best land on the tiny island is controlled by the royal family, often seized without due process.

While Bahrain has generally permitted greater freedom of speech than in many neighboring countries, criticism of the royal family - which applies to the government and most of its ministries - is significantly restricted. Similarly, laws against fomenting "sectarianism" have been broadly applied. This comes as no surprise, given that the royal family is Sunni and most opposition groups are based in the majority Shia community.

It is the disappointment from these promised but never fully-enacted reforms which has led the opposition to distrust promises of further reform and its reticence to engage in negotiations or compromise with the government.

Several political forces boycotted the October 2010 parliamentary elections, including the main opposition party Haq Movement for Liberty and Democracy (which includes both Shia and Sunni leadership) as well as the Wafa Party, the Bahrain Freedom Movement, the Khalas Movement, and the Islamic Action Society. Just prior to the vote, the authorities arrested a number of opposition leaders after they raised concerns about human rights abuses.

Bahrain, then, appeared to be ripe for revolt. In previous decades, largely nonviolent popular struggles had contributed to the downfall of scores of dictatorships from the Philippines to Poland and from Chile to Serbia. Beginning in Tunisia in December 2010, this trend came to the Arab world on an unprecedented scale.

A limited armed resistance struggle in Bahrain a few decades ago was quickly and easily suppressed. Armed resistance can terrify people not yet committed to the struggle, making it easier for a government to justify violent repression and use of military force in the name of protecting the population. The use of force against unarmed resistance movements, on the other hand, usually creates greater sympathy for the government's opponents. As with the martial art of aikido, nonviolent opposition movements can engage the force of the state's repression and use it to effectively disarm the force directed against them. In addition, unarmed campaigns involve a range of participants far beyond the young able-bodied men normally 
found in the ranks of armed guerrillas. As the movement grows in strength, it can include a large cross-section of the population. Though most repressive governments are well-prepared to deal with a violent insurgency, they tend to be less prepared to counter massive non-cooperation by the old, middle-aged, and young.

Nonviolent resistance recognizes that power comes ultimately not from the state or military force, but the willingness of a people to cooperate and obey.

Pro-government elements tend to be more willing to compromise with nonviolent insurgents, who are less likely to physically harm their opponents when they take power. Unarmed movements also increase the likelihood of defections and noncooperation by police and military personnel, who will generally fight in self-defense against armed guerrillas but are hesitant to shoot into unarmed crowds.

A 2005 study by Freedom House observed that, of the nearly 70 countries that have made the transition from dictatorship to varying degrees of democracy in the past 30 years, only a small minority did so through armed struggle from below or reform instigated from above. Hardly any new democracies resulted from foreign invasion. In nearly three-quarters of the transitions, change was rooted in democratic civil-society organizations that employed nonviolent methods. In addition, the study noted that countries where nonviolent civil resistance movements played a major role tend to have freer and more stable democratic systems. ${ }^{3}$

A different study, published in 2008 in the journal International Security, used an expanded database and analyzed 323 major insurrections in support of self-determination and democratic rule since 1900. It found that violent resistance was successful only 26 percent of the time, whereas nonviolent campaigns had a 53 percent success rate. ${ }^{4}$ Not all of these protests culminate in the kind of massive popular contestation of public space that caused a dictatorship to fall or a political system to collapse, as seen in Cairo, Tunis, Belgrade, Prague or Manila. More often, they have forced autocratic governments to negotiate a more gradual transfer of power.

However, even as the more repressive republican dictatorships in Tunisia and Egypt were toppled and protests in Yemen - despite a weaker civil society, a more factious political culture, and far greater poverty-forced the downfall of that country's longstanding president, the regime in Bahrain has thus far not only held on to power, but also resisted demands for serious reforms.

\section{Bahrain's Nonviolent Struggle}

Inspired by pro-democracy uprisings in Tunisia and Egypt, pro-democracy activists in Bahrain called for nationwide pro-democracy protests on February 14, 2011, the tenth anniversary of the National Action Charter referendum. The mostly young organizers called on Bahrainis "to take to the streets on Monday 14 February in a peaceful and orderly manner" in order to rewrite the constitution and establish a 
body with a "full popular mandate to investigate and hold to account economic, political and social violations, including stolen public wealth, political naturalisation, arrests, torture, and other oppressive security measures, [and] institutional and economic corruption."

The demands of the movement included the resignation of the prime minister, greater civil liberties, a unicameral elected legislature, a government elected by the people rather than by royal appointment, fair electoral districts based on one person one vote, an independent judiciary, and an army and security apparatus representative of the country's population. Importantly, rather than calling for the abolition of the monarchy, the protesters simply called for a constitutional monarchy more accountable to popular will.

According to the Bahrain Center for Human Rights (BCHR), the government's response was "a state of confusion, apprehension and anticipation," ${ }^{\text {" including an }}$ attempt to placate the opposition with money. The king ordered that 1,000 Bahraini dinars (approximately $\$ 2,600$ ) be distributed to each family in celebration of the referendum's tenth anniversary.

On February 12, the BCHR sent an open letter to the king to "ease tensions" and "avoid the use of force" by releasing 450 detainees, dissolving the security apparatus, prosecuting officials guilty of human rights violations, and beginning "serious dialogue with civil society and opposition groups on disputed issues." BCHR President Nabeel Rajab stated, "The dissolving of the security apparatus and the prosecution of its officials will not only distance the King from the crimes committed by this apparatus especially since 2005 , such as systemic torture and the use of excessive force against peaceful protests, but will avoid the fatal mistake committed by similar apparatuses in Tunisia and Egypt which led to the loss of lives and hundreds of casualties and eventually resulted in the fall of the regimes who created these "double edged swords." "7

When protests did break out across the country on February 14, the government responded with mass arrests and beatings, injuring dozens of demonstrators and killing one young man. At his funeral the following day, police shot into the crowd, killing an additional person and wounding 25 others. Al Wefaq, a predominantly Shia party that had won a plurality of seats in the recent parliamentary elections, announced a suspension of their participation in the parliament and formally joined the demonstrations. Tens of thousands of protesters occupied the Pearl Roundabout at the center of Manama, setting up tents in a manner similar to the mass sit-ins in Cairo's Tahrir Square.

At around 3:00am on February 17, without warning, riot police attacked the sleeping encampment of thousands with tear gas, batons, and bullets. Four more people were killed, including a two-year-old girl shot multiple times. Al Jazeera reported that hospitals in Manama were filled with hundreds of wounded protesters 
and described "doctors and emergency personnel who were overrun by the police while trying to attend to the wounded." ${ }^{8}$ Directly contradicting eyewitness accounts and video footage, the regime insisted the protesters had attacked the police and that security forces had used only minimal force in self-defense. Bahrain's government, like the dictatorial regimes in Egypt, Syria and Libya, tried to blame outsiders, claiming that it had found weapons and flags from the radical Lebanese group Hezbollah.

Despite such provocations, the opposition's response was largely peaceful. Pro-democracy activists gathered to pray and hold vigil outside hospitals. They engaged in more peaceful protests in the capital the following day. When confronted by security forces, protesters held their hands up high and shouted, "Peaceful! Peaceful!" Police and army units again attacked the demonstrators-along with mourners, journalists, and medics - resulting in one additional death and scores of injuries. ${ }^{9}$

As has often occurred elsewhere, when a government uses force against peaceful demonstrators, the protests increased in intensity rather than diminished. Recognizing this, the regime withdrew the military and police from the capital. Thousands of protesters returned to the Pearl Roundabout to resume their peaceful sit-in.

On February 22, more than 100,000 anti-government protesters took to the street. This time, the government allowed the demonstrators to march. Smaller protests continued over subsequent days. The government attempted to back down from its hard line stance - declaring a national day of mourning for those killed, freeing hundreds of political prisoners, dismissing four unpopular cabinet officials, allowing an exiled opposition leader to return, and making a series of economic concessions. On February 25, more than 200,000 people marched, a number constituting a full 40 percent of the indigenous Bahraini population. Over subsequent weeks, protests escalated further as demonstrators attempted to blockade the state television headquarters and the parliament building.

When the Bahraini regime proved incapable of suppressing the popular nonviolent uprising on its own, US-armed Saudi forces, supplemented by smaller units from the United Arab Emirates and other members of the Gulf Cooperation Council (GCC), invaded the country on March 14 via the causeway separating the island from the mainland. The regime declared a state of emergency and remaining protests were suppressed, resulting in five additional deaths. In a sign of its desperation and vindictiveness, the regime tore down the iconic pearl sculpture at the center of the Pearl Roundabout - the country's most famous structure which had become a symbol of the resistance movement - and even removed from circulation a coin which had its image. Local journalists were suppressed and a systematic crackdown on the media ensued, including suspending publication of the country's only independent newspaper. Foreign journalists were expelled from the country. 
As with guerrilla fighters struggling against a more powerful opponent, the nonviolent activists in Bahrain have subsequently engaged in a series of smaller scale actions, ranging from brief demonstrations in shopping malls to temporarily blocking major traffic arteries. While many of those rounded up by security forces were released, including all medical personnel, repression of peaceful protests continued.

On November 22, the government-appointed Bahrain Independent Commission of Inquiry, headed by former UN war-crimes lawyer Cherif Bassouini, publicly released a 500-page report before King Hamad and assembled journalists that was surprisingly frank in acknowledging many of the regime's abuses. Despite assumptions by most of the opposition that it would be a cover-up, observers were stunned to see the unprecedented sight of "an independent jurist standing before a Gulf monarch publicly accuse that monarch's government of systematic abuse." 10 Indeed, it was perhaps the most self-critical analysis of repression against an ongoing struggle ever published by an Arab government. While opposition critics noted it did not hold anyone in particular accountable, it did detail government violence, torture and other human rights violations. The report was also critical of the scattered acts of violence by some protesters and criticized the opposition for not taking advantage of offers of dialogue by the regime.

The king, however, remained defiant, refusing to acknowledge any of the report's findings, thanking security forces for restoring order and blaming Iran for the unrest. Indeed, the government did little in response other than to appoint another committee to examine the commission's recommendations, leading skeptics to speculate that it could result in an endless cycle of committee investigations which produce little in substance, particularly since they would likely continue to be created by royal decree rather than jointly appointed by representatives of the government and opposition.

Indeed, the day after the report was issued, security forces launched a new round of repression against the now smaller but still persistent protests. Meanwhile, leading opposition figures continued to refuse to cooperate with investigators. The tumultuous year ended when thousands protested on December 31 at the funeral of a 15 -year-old boy killed by government forces during a demonstration the previous day.

\section{The Iranian Bogeyman}

Nearly three-quarters of the indigenous Bahraini population are Shia, yet the Sunni-controlled Bahraini government has long discriminated against Shias in employment, housing, and infrastructure projects. The military, particularly the top elite, is mostly Sunni. The secret police are almost exclusively Sunni, and include Pakistanis and other foreign elements. Only a handful of cabinet posts, 
restricted to the less important ministries, have been granted to Shias. In an effort to bolster the number of Sunnis, the government has taken the unusual step of granting citizenship to some foreign Sunni workers, virtually unprecedented in other Gulf countries with large foreign worker populations. As a result, it is no surprise that a disproportionate percentage of the pro-democracy demonstrators have been Shia.

Such discrimination, however, is but one aspect of the monarchy's authoritarian rule which Bahrainis are challenging. Indeed, the protests in Bahrain are as legitimate a pro-democracy movement as the popular struggles in Tunisia, Egypt, Yemen, and Syria. Signs and chants at the demonstrations have eschewed sectarianism, emphasizing Shia-Sunni unity in the cause of democracy, and the protests have the support of both the progressive Sunni and secular populations. Though the red and white Bahraini flag has long been associated with the Sunni Khalifa dynasty, which conquered Bahrain in the late eighteenth century, the opposition has made a point of displaying it prominently in their demonstrations to demonstrate their loyalty to the nation rather than one branch of Islam.

Often when disenfranchised Shia populations in the Middle East have organized for their rights, Sunni regimes label the activists as Iranian agents. In some cases, Iranian intelligence has indeed supported these movements, although the vast majority of these protests have been popular indigenous struggles with legitimate grievances. The Iranian connection, however false or exaggerated, introduces the fear of an Iranian plot to assert their influence and establish an Iranian-style theocracy. Indeed, this has been the major component of the strategy used by the Bahraini regime to suppress the ongoing pro-democracy struggle, raising the specter of Iran as a means of gaining support among Bahrain's Sunni minority and Western governments.

However, most Bahraini Shias, unlike their counterparts in Iran and some other countries, do not follow ayatollahs. Those that do are more in the quietist tradition of those like Iraq's Ayatollah Sistani than those who advocate direct clerical rule. Furthermore, having been conquered by the Persian Empire for periods of their history, Bahrainis cherish their independence and roundly reject calls by some Persian ultra-nationalists to reincorporate Bahrain into Iran. While many Bahraini Shias were initially enthusiastic about the Islamic revolution in the immediate aftermath of the Shah's overthrow in 1979, they-like most Iranians themselveshave since soured on the revolution as a result of its reactionary and repressive turn. In addition, the Bahraini opposition movement has expressed its solidarity with the ongoing pro-democracy struggle against the Iranian-backed regime in Syria. Bahrain's most senior Shia cleric, Sheik Isa Qassim, has pointedly stressed that the Shias of Bahrain have no outreach to Iran. ${ }^{11}$

It also makes little sense that the Iranian regime - already concerned about the precedent of the largely nonviolent pro-democracy uprisings in Tunisia, Egypt, 
Yemen, Syria and elsewhere in the Middle East—would want to see a successful pro-democracy uprising in neighboring Bahrain, particularly one led by Shias. Given that the demands of the pro-democracy struggle in Bahrain and other Arab countries is virtually identical to that of the 2009 Green Revolution so brutally suppressed by the clerical leadership in Tehran, it is hard to imagine that Iran's repressive autocratic regime, which has shown little mercy in its repression of its own Shia population, would care more about the democratic rights of foreign Shias.

At the same time, because the Shia majority has the most to gain from democratic change, the protesters have indeed been overwhelmingly Shia. The Bahraini government, in a divide-and-rule strategy, has raised the specter of a Shiite fundamentalist takeover in an effort to enlist the sizable Sunni minority in protecting their privileged status, thereby creating the potential for a self-fulfilling prophecy of a polarization of Bahraini society along sectarian lines. Indeed, it was no accident that a pro-government rally organized by the regime took place in the plaza near the grand Sunni mosque - a rally thousands of resident Indian and Pakistani Sunnis were encouraged to join.

The exaggerated view of Iranian meddling became the central rationale for the intervention by Saudi troops, which was launched under the guise of the GCC treaty which grants the right to such intervention in order to resist foreign aggression.

Despite the Bahraini government's insistence that Iran is behind the uprising, its own commission's report published in November 2011 found no "discernible link between specific incidents that occurred... and the Islamic Republic of Iran." 12

Despite this, King Hamad and other government officials continue to insist Iran is supporting the anti-government protests, as have pro-regime elements of the Obama administration. For example, Obama's recently-retired special Middle East advisor Dennis Ross emphasized alleged Iranian support for the opposition and condemned alleged Iranian meddling while downplaying repression by the Bahraini government. ${ }^{13}$ Even President Obama himself has accused Iran of having allegedly "tried to take advantage of the turmoil" in Bahrain. ${ }^{14}$ By contrast, Obama has refused to endorse international demands that Saudi Arabia and allied emirates withdraw the troops they sent into that island kingdom to crush pro-democracy forces or any other criticism of the Saudi invasion.

\section{The Ties that Bind}

The Obama administration's failure to criticize Saudi aggression and its willingness to accept the regime's claims of Iranian interference are but two examples of how Washington has disappointed pro-democracy activists in the kingdom.

On February 15, 2011, in the aftermath of the nonviolent overthrow of Egyptian dictator Hosni Mubarak, President Obama warned other Middle Eastern leaders that 
they should "get ahead of the wave of protest" by quickly moving toward democracy. Even though his press conference took place during some of the worst repression in Bahrain, however, he chose not to mention the country by name. In the face of Bahraini security forces unleashing violence on peaceful protesters, Obama insisted that "each country is different, each country has its own traditions; America can't dictate how they run their societies." ${ }^{15}$ Although certainly a valid statement in itself, in this case it appears to have been little more than a rationalization for silence in the face of extreme violence by an autocratic ally. Indeed, critics have contrasted the initially understated US response to the repression by the allied Bahraini regime with sanctions against Syria and direct military intervention in Libya, even thoughunlike these other two cases - no one in the Bahraini opposition has taken up arms.

Meanwhile, on February 23, US Admiral Mike Mullen, chairman of the Joint Chiefs of Staff, came to Bahrain to meet King Hamad and Crown Prince Salman, who serves as commander-in-chief for the Bahraini armed forces. According to Mullen's spokesman, Navy Captain John Kirby, the admiral "reaffirmed our strong commitment to our military relationship with the Bahraini defense forces." And, despite the massacres of the previous week, he thanked the Bahraini leaders "for the very measured way they have been handling the popular crisis here."16

Indeed, on February 25 the New York Times reported how the Obama administration "has sent out senior diplomats in recent days to offer the monarchs reassurance and advice - even those who lead the most stifling governments." The article stressed that the administration is not averse to encouraging reforms, noting however that "American officials have sought to keep the focus on what they insist have been concessions made by Bahrain, where the Navy's Fifth Fleet is stationed, as a sign that the protests can prod the king, and the crown prince who will head the dialogue with the protesters, in the right direction." 17

President Obama did contact King Hamad directly on at least one occasion in February to voice his concerns about the repression. In addition, investigations were launched as to whether, under the Leahy Amendment, US military aid to various units of Bahrain's security forces should be suspended due to human-rights violations. While some White House officials were encouraging the administration to take a forceful stand in support for human rights, Secretary of Defense Robert Gates and Secretary of State Hillary Clinton pushed back in support for the Bahraini regime. In early March, the Wall Street Journal reported that "the administration has moved a few notches toward emphasizing stability over majority rule. Everybody realized that Bahrain was just too important to fail." 18

In his May 19 speech on US Middle East policy, making his most forceful public comments on the situation in Bahrain to date, Obama addressed concerns about the worsening repression in that island kingdom, noting "we have insisted publicly and privately that mass arrests and brute force are at odds with the universal rights 
of Bahrain's citizens, and will not make legitimate calls for reform go away. The only way forward is for the government and opposition to engage in a dialogue, and you can't have a real dialogue when parts of the peaceful opposition are in jail. The government must create the conditions for dialogue, and the opposition must participate to forge a just future for all Bahrainis." 19

He did not, however, call on King Hamad to lead a transition to democracy "or get out of the way" as he did during that same speech in regard to Syrian President Hafez Assad, even though at the time more pro-democracy activists had been killed and jailed relative to population in Bahrain than in Syria.

At his September 21 speech at the United Nations, Obama became the first American president to mention Bahrain in a UN address. While critics charged that he downplayed the repression in Bahrain and exaggerated the government's reform efforts, he nevertheless was willing to express his ongoing concern: "In Bahrain, steps have been taken toward reform and accountability. We're pleased with that, but more is required. America is a close friend of Bahrain, and we will continue to call on the government and the main opposition bloc - the Wifaq-to pursue a meaningful dialogue that brings peaceful change that is responsive to the people. ${ }^{" 20}$ Critics, however, note that while dialogue is indeed essential and compromise on both sides is presumably necessary Obama's approach assumes symmetry in power between the government and opposition which does not exist; nor does it take into account the enormous leverage Washington could exert on the government if it chose to.

The president sounded an optimistic note in observing that "We believe the patriotism that binds Bahrainis together must be more powerful than the sectarian forces that would tear them apart. It will be hard, but it is possible. ${ }^{21}$ He failed to mention, however, that it has been Bahrain's government and its supporters, not the pro-democracy opposition, which has been playing the sectarian card. For example, it is the regime and its backers that have destroyed Shia mosques, not oppositionists destroying Sunni mosques.

The fine line Obama has been forced to walk on Bahrain is tied to the island nation's important strategic role for the United States.

The US military in Bahrain, which directs the Fifth Fleet and the US Naval Central Command, controls roughly one-fifth of this small nation. For more than 20 years, approximately 1,500 Americans have been stationed at what the US government refers to as a "forward operations center," supporting operations and serving as homeport for an additional 15,000 sailors. Unlike in other Gulf states, where Americans have traditionally tried to keep a low profile, the US presence is quite visible in Bahrain as a major port of call for sailors on leave. The fortress-like US embassy in Manama is probably the largest embassy relative to the population of the host country of any in the world. 
Bahrain purchased more that $\$ 386$ million in weaponry, ammunition and fighting vehicles from the United States between 2007 and 2009. As University of California-Irvine Professor Mark LeVine describes it, "If the United States is Egypt's primary patron, in Bahrain it is among the ruling family's biggest tenants." 22 Former Chairman of the Joint Chiefs of Staff Admiral William Crowe once told me in an interview that Bahrain was "pound for pound, man for man, the best ally the United States has anywhere in the world."23

Indeed, economic interests also draw the two nations together. Bahrain was the first Arab country to produce oil back in 1932. Standard Oil of California (now Chevron), later joined by Texaco, succeeded in controlling the country's oil industry through ownership of the Bahrain Petroleum Company, until the Bahraini government purchased the company in 1980. The government has embarked upon a massive privatization program in recent years - selling banks, financial services, telecommunication, and other public assets to private interests. The Heritage Foundation/Wall Street Journal Index of Economic Freedom ranks Bahrain as having the "freest" economy in the Middle East and the tenth "freest" in the world.

Support for the neo-liberal "Washington consensus" resulted in Bahrain becoming the first Persian Gulf state to sign a free trade agreement with the United States in 2005. In response to the recent arrests and firings of trade union activists by the Bahraini regime, the AFL-CIO has called on the Obama administration to suspend the special accord that waives tariffs on industrial and consumer products, the first time the US trade union federation has called for halting a trade pact on human rights grounds. The Obama administration, however, has rejected the plea.

Unfortunately, rather than advocating sanctions, as the president has done with Syria, the US Defense Department announced just a week before Obama's September UN speech a proposed sale of \$53 million of weapons and related equipment to Bahrain's military, including 44 armed Humvees that could be important instruments in suppressing street protests. The Pentagon, in defending the arms transfer, praised the authoritarian government as "an important force for political stability and economic progress in the Middle East."24

According to Maria McFarland, deputy Washington director at Human Rights Watch, "This is exactly the wrong move after Bahrain brutally suppressed protests and is carrying out a relentless campaign of retribution against its critics. It will be hard for people to take U.S. statements about democracy and human rights in the Middle East seriously when, rather than hold its ally Bahrain to account, it appears to reward repression with new weapons." ${ }^{25}$

In response, a broad coalition of 29 peace, human rights, and religious organizations mobilized against the arms sale and a number of prominent Congressional Democrats raised concerns as well. Opponents of US policy in Bahrain emphasized that, for the cause of freedom and democracy to advance in the Arab world, the struggle cannot 
just take place in the Middle East, but in the United States as well. The following month, in the face of mounting objections, the Obama administration announced an indefinite delay in the sale, while continuing, according to a State Department official, to "supply some items on a case-by-case basis that directly affected our own national security interests." 26

In May of 2012, however, the Obama administration announced they were releasing much of the items that had previously been put on hold, though emphasized that they were primarily for external defense and "not typically used for crowd control and we would not anticipate would be used against protestors in any scenario." When pressed by reporters to describe which specific items were included in the package, however, State Department officials refused to elaborate, making it impossible to actually verify whether the arms transfers did not include tools of repression. ${ }^{27}$

\section{Conclusion}

A more democratic Bahrain would probably be friendlier to the Iranian regime than the current Bahraini government, but it would certainly not be an Iranian puppet. For example, the Sultanate of Oman, an Arab member of the GCC, still has longstanding cultural and commercial ties with Iran. Opposition forces have stressed they would not call for the removal of US forces from the country, but even if a more democratic Bahrain did scale back the US military presence on their small island, it would not be stridently anti-American. Questions remain as to how much democracy the United States would like to see in the region, even if led by a popular mass nonviolent movement. Putting the normative arguments aside, however, anything short of support for full democratization would be extremely short-sighted. As Professor Levine puts it, "What is more essential to American security today, convenient bases for its ships, planes and troops across the Middle East, or a full transition to democracy throughout the region?"28

Nabeel Rajab, president of the Bahrain Center for Human Rights and recipient of the Woodrow Wilson Center's 2011 Ion Ratiu Democracy Award, noted that while human rights groups and civil society organizations have supported democratic struggles in the Gulf region, the Obama administration's policies have been disappointing, noting how "the U.S. has acted differently and has different responses for different countries. There is full support for revolutions in countries where [the U.S. government] has a problem with their leadership, but when it comes to allied dictators in the Gulf countries, they have a much softer position and that was very upsetting to many people in Bahrain and the Gulf region. This will not serve your long strategic interest, to strengthen and continue your relations with dictators 
and repressive regimes," noting how "Those dictators will not be there forever. Relationships should be maintained with people, not families." 29

Among the problems this double-standard creates is that it has enabled the Syrian regime and its supporters to make the case that opposition to repression by the Assad government is not based on a universal commitment to human rights and democracy, but simply a means to destabilize a country whose leadership has not been supportive of Western interests.

In both Tunisia and Egypt, the United States had to play catch up in its policy toward these allied regimes in the face of popular struggles against authoritarianism, only belatedly coming out in support of the massive nonviolent pro-democracy struggles in those countries. It would be nice if, when it comes to Bahrain, the United States would not wait until the last minute to be on the right side of history.

\section{Notes}

1. Human Rights Watch, "Joint Letter to US Congress Regarding Arms Sale to Bahrain," September 27, 2011.

2. Department of State, 2010 Human Rights Report: Bahrain.

3. Adrian Karatnycky and Peter Ackerman, How Freedom is Won: From Civil Struggle to Durable Democracy (Freedom House, 2005).

4. Maria Stephan and Erica Chenoweth, "Why Civil Resistance Works: The Strategic Logic of Nonviolent Conflict," International Security 33:1, 7-44.

5. "A Statement by Bahraini Youth for Freedom," Bahrainonline, February 12, 2011.

6. "Authorities block page of online group calling for demonstrations," International Freedom of Expression Exchange, February 6, 2011.

7. Bahrain Center for Human Rights, "An open letter to the King of Bahrain to avoid the worst case scenario," February 12, 2011.

8. Al Jazeera, "Clashes rock Bahraini capital," February 17, 2011.

9. Adrian Blomfield, "Bahrain royal family orders army to turn on the people," The Telegraph, February 18, 2011.

10. Joost Hiltermann and Kelly McEvers, "Barricaded in Bahrain," New York Review of Books Blog, December 27, 2011.

11. Huffington Post, "Bahrain protests: Opposition rally draws more than 10,000," June 11, 2011.

12. Cited in Hiltermann and McEvers, "Barricaded in Bahrain."

13. Dennis Ross, address before the annual meeting of the Center for the Study of Islam and Democracy, Washington, DC, April 15, 2011.

14. Office of the Press Secretary, "Remarks by the President on the Middle East and North Africa," The White House, May 19, 2011.

15. Office of the Press Secretary, Press Conference by the President, The White House, February 15, 2011.

16. Donna Miles, "Mullen reaffirms American-Bahraini alliance," American Forces Press Service, February 25, 2011.

17. Mark Lander and Helene Cooper, "U.S. trying to pick winners in new Mideast," New York Times, February 24, 2011.

18. Adam Entous and Julian E. Barnes, "U.S. wavers on 'regime change'," Wall Street Journal, March 5,2011 . 
19. Office of the Press Secretary, "Remarks by the President on the Middle East and North Africa," The White House, May 19, 2011.

20. Office of the Press Secretary, "Remarks by President Obama in Address to the United Nations General Assembly," The White House, September 21, 2011.

21. Ibid.

22. Mark LeVine, "Here we go again: Egypt to Bahrain," Al Jazeera English, February 18, 2011.

23. Interview with author, US Embassy, Manama, Bahrain, January 8, 1992.

24. Defense Security Cooperation Agency, News Release: Bahrain-M1152A1B2 HMMWVs and TOW-2A and TOW-2B Missiles, September 14, 2011.

25. Human Rights Watch, "US: Stop proposed arms sales to Bahrain," September 22, 2011.

26. US Department of State, Special Briefing, Senior Administration Officials, Via Teleconference, May 11, 2012.

27. Ibid.

28. LeVine, "Here we go again."

29. Cited in Josh Rogin, "Is the U.S. on the wrong side of history in Bahrain," Foreign Policy, December 6, 2011. 